\title{
SURVEY KEPADATAN LARVA AEDES AEGYPTI DI KECAMATAN MAMUJU KABUPATEN MAMUJU
}

\author{
Zrimurti Mappau, Siti Rahmah, Ridhayani Adiningsih \\ Jurusan Kesehatan Lingkungan Poltekkes Kemenkes Mamuju
}

\begin{abstract}
Aedes aegypti is a vector of dengue fever. Vector density may be effect of disease incidence because of the high density and highly resistant to increase of the disease. Larvae density in an area influenced by availabiloty of kontainers. The objective of this study to determine of larvae density of Aedes aegypti mosquito in endemic and non endemic area in Mamuju District based on House Index value, Kontainer Index value, Breteau Index value, and Density Figure level. We did observasional study with cross sectional by collected data and observation to larvae density of Aedes aegypti in its kontainers. Sample size determination using simple random sampling Lemeshow formula as much as 340 in endemic area and 295 in non endemic area. Based on density figure level, endemic and non endemic area included in average category so that area potential for the occurance of infection.
\end{abstract}

\section{Keyword: Aedes aegypti, Larvae density}

\section{PENDAHULUAN}

Demam Berdarah Dengue pertama kali ditemukan di Indonesia tahun 1968 di Jakarta dan Surabaya. Setiap tahun Indonesia merupakan daerah endemis DBD. Tahun 2010 Indonesia menempati urutan tertinggi kasus DBD di Asean dengan jumlah kasus 156.086 dan kematian 1.358 orang. Demam Berdarah Dengue (DBD) adalah penyakit menular yang disebabkan oleh virus dengue dengan tandatanda tertentu dan disebarkan melalui gigitan nyamuk Aedes aegypti. Kasus DBD setiap tahun di Indonesia terus meningkat dan bahkan makin merajalela dengan pemanasan global. Data kementerian menunjukkan jumlah kasus DBD di Indonesia selama 2009 mencapai 77.489 kasus dengan 585 korban meninggal. Tahun 2010 Indonesia menempati urutan tertinggi kasus DBD di Asean dengan jumlah kasus 156.086 dan kematian 1.358 orang . Direktorat Jenderal Pemberantasan Penyakit dan Penyehatan Lingkungan, melaporkan kasus DBD tahun 2011 di Indonesia menurun dengan jumlah kasus 49.486 dan jumlah kematian 403 orang (Kementerian Kesehatan RI, 2011).

Diketahui bahwa tahun 2011 kasus

Demam Berdarah Dengue di Kabupaten Mamuju tercatat 173 orang menderita DBD dan kematian hanya 1 orang. Tahun 2012 jumlah kasus DBD tercatat 100 orang dan meninggal 1 orang. Angka kejadian kasus tertinggi pada wilayah Puskesmas Binanga di lima Kelurahan berturut-turut dari tahun $2013 \quad 85$ Kasus meninggal 1 orang dan 2014 sebanyak 48 orang tidak ada yang meninggal (Dinas Kesehatan Kabupaten Mamuju, 2016).

Tingginya angka kejadian kasus penyakit Demam Berdarah Dengue yang selalu berfluktuasi dan hampir terjadi setiap tahun yang disebabkan oleh virus dengue dan ditularkan melalui gigitan nyamuk Aedes aegypti betina. Sebagai pembawa virus dengue, Aedesaegypti merupakan pembawa utama (Primary Vector) dan bersama Aedes albopictus menciptakan siklus persebaran dengue di desa dan kota (Kementerian Kesehatan RI, 2011).

Jumlah populasi nyamuk dewasa maupun larva Aedes aegypti berhubungan erat dengan peningkatan kasus DBD. Populasi nyamuk ini sangat didukung oleh ketersediaan tempatnya untuk berkembangn biak dimana tempat potensial untuk perindukan nyamuk Aedes aegypti adalah tempat Penampungan Air (TPA) yang digunakan sehari-hari, yaitu drum, bak mandi, bak WC, gentong, ember dan lainlain. Tempat perindukan lainnnya yang non TPA adalah vas bunga, ban bekas, botol bekas, serta TPA alamiah yaitu lubang pohon, daun pisang, pelepah daun keladi, lubang batu, dan lain-lain. Adanya kontainer di rumah ataupun bangunan lainnya bahkan saluran air hujan yang tidak lancar disekitar rumah juga merupakan tempat perkembangbiakan yang baik (Soegijanto, 2006).

Kepadatan vektor juga bisa berpengaruh terhadap kejadian penyakit karena tingginya densitas sangat resisten untuk peningkatan angka kejadian penyakit itu sendiri. Informasi kepadatan vektor diperlukan 
sebagai salah satu indikator potensi penularan virus dengue (WHO, 2004).

Tujuan dari penelitian ini adalah untuk mengetahui kepadatan larva Nyamuk Aedes aegypti didaerah endemis dan tidak endemis di Kecamatan Mamuju Kabupaten Mamuju Provinsi Sulawesi Barat berdasarkan Nilai House Indeks, Kontainer Indeks, Breteau Indeks, dan Level Density Figure.

\section{METODE}

\section{Jenis Penelitian}

Penelitian ini merupakan penelitian observasional dengan jenis penelitian cross sectional dengan melakukan pengumpulan data dan observasi terhadap kepadatan larva Aedes aegypti di tempat-tempat perindukannya.

\section{Lokasi dan Waktu Penelitian}

Penelitian ini dilaksanakan di Kecamatan Mamuju Kabupaten Mamuju Provinsi Sulawesi Barat pada bulan Januari - Desember 2015.

\section{Populasi dan Sampel}

Populasi dalam penelitian ini yaitu seluruh rumah pada Kecamatan Mamuju khususnya kelurahan endemis yaitu di Kelurahan Binanga sebanyak 2840 KK dan non endemis di Kelurahan Mamunyu sebanyak 1256 KK. Penentuan besar sampel dalam penelitian inimenggunakan rumus simple random sampling Lemeshow dengan jumlah rumah dikelurahan endemis di Kelurahan Binanga sebesar 340 KK dan tidak endemis di Kelurahan Mamunyu sebanyak 295 KK.

\section{Teknik Pengumpulan Data}

Teknik pengumpulan data adalah dengan melakukan survei langsung di lapangan dengan pengambilan sampel menggunakan metode simple random sampling yaitu mengambil sampel secara acak namun bisa mewakili data keseluruhan.

\section{Variabel Penelitian}

Variabel terikat adalah variabel yang dipengaruhi oleh variabel bebas dalam penelitian ini adalah Larva Indeks atau kepadatan larva Aedes aegypti. Variabel bebas adalah variabel yang diduga berpengaruh terhadap variabel terikat dalam penelitian ini nilai House Indeks, nilai Kontainer Indeks, Nilai Breteau Indeks dan Level Density Figure terhadap kepadatan larva.

\section{HASIL PENELITIAN}

Survey kepadatan larva dapat dijadikan sebagai salah satu indikator tingginya kasus penyakit DBD. Survey tersebut dilakukan untuk membandingkan kepadatan larva di daerah endemis dan non endemis.

Tabel 1. Distribusi Frekuensi Kontainer dalam Rumah yang Ditemukan di Daerah Endemis

\begin{tabular}{lcccccc}
\hline Nama Kontainer & Positif & \% & Negatif & \% & Total & \% \\
\hline Vas Bunga & 2 & 5 & 44 & 7 & 46 & 7 \\
Ember & 6 & 15 & 196 & 31 & 202 & 31 \\
Gentong & 5 & 12 & 72 & 11 & 77 & 11 \\
Bak Mandi & 27 & 66 & 258 & 42 & 285 & 42 \\
Baskom & 1 & 2 & 15 & 2 & 16 & 2 \\
Drum & 0 & 0 & 10 & 1 & 10 & 1 \\
Jerigen & 0 & 0 & 38 & 6 & 38 & 6 \\
\multicolumn{1}{r}{ Total } & $\mathbf{4 1}$ & $\mathbf{1 0 0}$ & $\mathbf{6 7 4}$ & $\mathbf{1 0 0}$ & $\mathbf{6 7 4}$ & $\mathbf{1 0 0}$ \\
\hline
\end{tabular}

Pada tabel 1 terlihat bahwa jenis kontainer sebagai tempat perindukan nyamuk terdapat paling banyak adalah bak mandi sebesar $42 \%$ kemudian ember sebesar $31 \%$ dan jenis paling sedikit adalah pada drum sebesar 1\%. Pada tabel 2 terlihat bahwa jenis kontainer sebagai tempat perindukan nyamuk terdapat paling banyak adalah pot bunga sebesar $22 \%$ dan jenis paling sedikit adalah pada drum, kolam, dan gentong yaitu masing-masing sebesar $1 \%$.

Pada tabel 3 terlihat bahwa jenis kontainer sebagai tempat perindukan nyamuk terdapat paling banyak adalah ember yaitu $36 \%$ dan jenis paling sedikit adalah piring bekas $0,1 \%$. Pada tabel 4 terlihat bahwa jenis kontainer sebagai tempat perindukan nyamuk terdapat paling banyak adalah pot bunga yaitu $36 \%$ dan jenis paling sedikit adalah pada toples, 
kaleng bekas dan bak yaitu masing sebesar $0,2 \%$.

Tabel 2. Distribusi Frekuensi Kontainer yang Ditemukan pada Luar Rumah Di Daerah Endemis

\begin{tabular}{lcccccc}
\hline \multicolumn{1}{c}{ Nama Kontainer } & Positif & $\mathbf{\%}$ & Negatif & \% & Total & \% \\
\hline Pot bunga & 6 & 7 & 368 & 23 & 374 & 22 \\
Ember & 17 & 22 & 143 & 9 & 160 & 9 \\
Ban bekas & 43 & 52 & 96 & 6 & 139 & 8 \\
Gelas plastic & 4 & 5 & 290 & 18 & 294 & 17 \\
Botol bekas & 3 & 4 & 329 & 22 & 332 & 19 \\
Batok kelapa & 0 & 0 & 165 & 10 & 165 & 10 \\
Kulit coklat & 1 & 1 & 129 & 8 & 130 & 8 \\
Ketiak pohon & 1 & 1 & 39 & 2 & 40 & 2 \\
Jergen & 2 & 2 & 39 & 2 & 41 & 2 \\
Drum & 3 & 4 & 4 & 0 & 7 & 1 \\
Kolam & 0 & 0 & 1 & 0 & 1 & 1 \\
Gentong & 2 & 2 & 1 & 0 & 3 & 1 \\
\multicolumn{1}{c}{ Total } & $\mathbf{8 2}$ & $\mathbf{1 0 0}$ & $\mathbf{1 6 0 4}$ & $\mathbf{1 0 0}$ & $\mathbf{1 6 8 6}$ & $\mathbf{1 0 0}$ \\
\hline
\end{tabular}

Tabel 3. Distribusi Frekuensi Kontainer yang ditemukan dalam rumah di daerah Non Endemis

\begin{tabular}{lcccccc}
\hline \multicolumn{1}{c}{ Kontainer } & Positif & \% & Negatif & \% & Total & \% \\
\hline Bak Mandi & 19 & 39 & 160 & 17 & 179 & 18 \\
Ember & 11 & 23 & 352 & 37 & 363 & 36 \\
Gentong & 9 & 18 & 170 & 18 & 179 & 18 \\
Baskom & 4 & 8 & 98 & 10 & 102 & 10 \\
Jergen & 5 & 10 & 145 & 15 & 150 & 15 \\
Drum & 0 & 0 & 4 & 0.4 & 4 & 0.4 \\
Vas Bunga & 0 & 0 & 19 & 2 & 19 & 1.9 \\
Piring Bekas & 1 & 2 & 0 & 0 & 1 & 0.1 \\
Galon & 0 & 0 & 6 & 0.6 & 6 & 0.6 \\
\multicolumn{1}{r}{ Total } & $\mathbf{4 9}$ & $\mathbf{1 0 0}$ & $\mathbf{9 5 4}$ & $\mathbf{1 0 0}$ & $\mathbf{1 0 0 3}$ & $\mathbf{1 0 0}$ \\
\hline
\end{tabular}

Pada tabel 5 Nilai House index untuk daerah endemis lebih besar dibandingkan dengan $\mathrm{HI}$ pada daerah non endemis yaitu $34 \%$ dan $15 \%$ dengan Nilai Kontainer Indeks CI adalah 5\% dan 6\% dengan nilai Breteau Indeks adalah $105 \%$ dan $32 \%$.

\section{PEMBAHASAN}

\section{Kepadatan Larva di Wilayah Endemis}

Berdasarkan hasil penelitian yang telah dilakukan di wilayah endemis yaitu di Kelurahan Binanga dari 340 rumah yang telah diperiksa ditemukan rumah positif larva 117 dengan jumlah kontainer 2360 dan kontainer positif 123. Dari jumlah tersebut diperoleh jenis kontainer dalam rumah yang paling banyak adalah bak mandi $42 \%$, ember $31 \%$ dan gentong masing-masing $11 \%$ dan yang paling kecil adalah drum $1 \%$. Sedangkan untuk diluar rumah jenis kontainer lebih banyak yaitu 12 jenis kontainer dengan jenis kontainer yang terbanyak adalah pot bunga sebesar $22 \%$, botol bekas $19 \%$ dan gelas plastik $17 \%$ ember $9 \%$, batok kelapa $10 \%$ dan yang paling sedikit jenis kontainer adalah drum, gentong, dan kolam yaitu masing-masing 1\%. Lebih banyaknya jenis kontainer yang ditemukan diluar rumah dibandingkan didalam rumah karena ditemukannya beberapa jenis kontainer alami seperi ketiak daun, batok kelapa dan kulit cokelat serta pot bunga yang lebih banyak ditemukan diluar rumah dibandingkan dengan dalam rumah. 
Tabel 4. Distribusi Frekuensi Kontainer yang ditemukan di luar rumah di daerah Non Endemis

\begin{tabular}{|c|c|c|c|c|c|c|}
\hline Nama Kontainer & Positif & $\%$ & Negatif & $\%$ & Total & $\%$ \\
\hline Gelas Plastik & 3 & 7 & 119 & 12 & 122 & 14 \\
\hline Botol & 2 & 4 & 122 & 14 & 124 & 15 \\
\hline Gentong & 3 & 7 & 6 & 0.8 & 9 & 1 \\
\hline Ketiak Pohon & 3 & 7 & 34 & 4 & 37 & 4 \\
\hline Jergen & 0 & 0 & 17 & 2 & 17 & 2 \\
\hline Ember & 5 & 11 & 108 & 13 & 113 & 12 \\
\hline Drum & 1 & 2 & 5 & 0.6 & 6 & 0.6 \\
\hline Pot Bunga & 7 & 16 & 321 & 38 & 328 & 36 \\
\hline Batok Kelapa & 14 & 30 & 66 & 8 & 80 & 8 \\
\hline Kulit Coklat & 0 & 0 & 3 & 0.4 & 3 & 0.4 \\
\hline Ban Bekas & 7 & 16 & 41 & 5 & 48 & 5 \\
\hline Toples Plastik & 0 & 0 & 1 & 0.2 & 1 & 0.2 \\
\hline Kaleng Bekas & 0 & 0 & 1 & 0.2 & 1 & 0.2 \\
\hline Baskom & 0 & 0 & 8 & 0.9 & 8 & 0.7 \\
\hline Galon & 0 & 0 & 2 & 0.3 & 2 & 0.3 \\
\hline Bak Mandi & 0 & 0 & 1 & 0.2 & 1 & 0.2 \\
\hline Daun Pisang & 0 & 0 & 3 & 0.4 & 3 & 0.4 \\
\hline Total & 45 & 100 & 858 & 100 & 903 & 100 \\
\hline
\end{tabular}

Tabel 5. Nilai House Indeks (HI), Nilai Kontainer Indeks (CI), Breteau Indeks (BI) dan Density Figure (DF) di Daerah Endemis dan Non Endemis

\begin{tabular}{|c|c|c|c|c|c|c|}
\hline \multirow{2}{*}{ Diperiksa } & \multirow{2}{*}{ Jumlah } & \multicolumn{2}{|c|}{ Larva } & \multirow{2}{*}{ HI } & \multirow{2}{*}{$\mathbf{C I}$} & \multirow{2}{*}{ BI } \\
\hline & & + & - & & & \\
\hline \multicolumn{7}{|l|}{ Endemis } \\
\hline Rumah & 340 & 117 & 223 & $34 \%$ & $5 \%$ & $105 \%$ \\
\hline Kontainer & 2360 & 123 & 2237 & $34 \%$ & $5 \%$ & $105 \%$ \\
\hline \multicolumn{4}{|c|}{ Level Density Figure } & 5 & 2 & 8 \\
\hline \multicolumn{7}{|l|}{ Non Endemis } \\
\hline Rumah & 295 & 45 & 250 & \multirow{2}{*}{$15 \%$} & \multirow{2}{*}{$6 \%$} & \multirow{2}{*}{$32 \%$} \\
\hline Kontainer & 1906 & 94 & 1812 & & & \\
\hline \multicolumn{4}{|c|}{ Level Density Figure } & 3 & 2 & 4 \\
\hline
\end{tabular}

Pada penelitian ini ditemukan jumlah jenis kontainer positif didalam rumah terbanyak adalah bak mandi, sehingga penelitian ini sejalan dengan penelitian yang dilakukan di Kelurahan Paseban Jakarta Pusat yang menyebutkan bahwa kontainer positif terbanyak ditemukan adalah bak mandi dan ember yaitu sebesar $61 \%$ dari beberapa jenis kontainer lainnya (Ramadhani, 2013).

Selain itu juga banyaknya kontainer positif pada bak mandi dapat dipengaruhi oleh volume air. Keira menyatakan bahwa kontainer dengan volumen air lebih dari dua liter merupakan salah tempat yang disukai oleh larva nyamuk Aedes aegypti karena dapat hidup dengan tenang.

Kepadatan Larva nyamuk Aedes aegypti dengan nilai House Indeks sebesar 34 $\%$. House Index merupakan salah satu indikator yang digunakan untuk menghitung resiko penyebaran penyakit. Indeks ini memberikan petunjuk tentang persentase rumah yang positif untuk perkembangbiakan dengan dan itu menunjukkan populasi manusia yang beresiko terkena DBD. Kontainer indeks memberikan gambaran presentae kontainer yang positif jentik Aedes. Dimana pada penelitian ini ditemukan nilai Kontainer Indeks (CI) sebesar 
5\% dan Breteau Indeks (BI) sebesar 102\%. Dengan nilai skala Density figure untuk nilai HI dan CI pada skala 2 - 4 yang mengindikasikan resiko penularan sedang. Sedangkan untuk nilai Breteau Indeks sebesar 105\% yang menandakan pada skala nilai Density figure merupakan daerah yang beresiko tinggi untuk terjadinya penularan. Nilai breteau indeks lebih baik digunakan dalam menentukan resiko peneluran karena nilai merupakan hasil dari nilai jumlah yang rumah diperiksa dibagi dengan jumlah seluruh kontainer.

Perbedaan jumlah jenis kontainer yang terbesar dikedua wilayah ini dapat disebabkan oleh perbedaann letak geografis dimana wilayah non endemis meskipun jaraknya masih dekat dengan kota tetapi memiliki letak geografis pengunungan dimana masyarakatnya umumnya belum memiliki sumber air dirumah masing. Berbeda dengan wilayah endemis yang memang letakknya ada diwilayah perkotaan yang umumnya menggunkan sumber air perpipaan sehingga di rumah-rumah banyak menggunakann kolam untuk menampung air.

Jenis kontainer yang lebih banyak ditemukan diluar rumah dibandingkan dalam rumah. Pada tempat perindukan larva nyamuk di luar rumah ditemukan tumbuhan pelindung seperti pohon pisang, pohon cokelat dan pohon mangga (Penturi, 2011). Kehidupan larva nyamuk dapat dipengaruhi oleh tumbuhtumbuhan semak karena dapat menghalangi larva dari sinar matahari langsung (Departemen Kesehatan RI, 2015).

\section{Kepadatan Larva di Wilayah Non Endemis}

Berdasarkan hasil penelitian yang telah dilakukan di Kelurahan Mamunyu yang merupakan wilayah non endemis dari 295 rumah yang telah diperiksa ditemukan sebanyak 1906 kontainer dengan 15 jenis kontainer. Dari jumlah tersebut diperoleh kontainer dalam rumah yang paling banyak adalah ember $36 \%$, bak mandi dan gentong masing-masing $18 \%$, jerigen $15 \%$, baskom $10 \%$ dan yang paling kecil adalah piring bekas $1 \%$. Sedangkan untuk diluar rumah jenis kontainer lebih banyak yaitu 15 jenis kontainer dengan jenis kontainer yang terbanyak adalah pot bunga sebesar $36 \%$, botol $15 \%$ dan gelas plastik $14 \%$ ember $12 \%$, batok kelapa 8\% dan yang paling sedikit jenis kontainer adalah toples bekas, bak dan kaleng bekas yaitu masing-masing 2\%. Lebih banyaknya jenis kontainer yang ditemukan diluar rumah dibandingkan didalam rumah karena ditemukannya beberapa jenis kontainer alami seperi ketiak daun, batok kelapa dan kulit cokelat serta pot bunga yang lebih banyak ditemukan diluar rumah dibandingkan dengan dalam rumah.

Pada penelitian ini ditemukan jumlah jenis kontainer positif didalam rumah terbanyak adalah ember, sehingga penelitian ini sejalan dengan penelitian yang dilakukan di Kecamatan Tikalo Manado yang menyebutkan bahwa kontainer positif terbanyak ditemukan adalah ember $40,7 \%$ serta pada penelitian yang dilakukan di Pangandaran juga diperoleh jumlah jenis kontainer positif terbanyak adalah ember sebesar 57,24\% (Hendri, 2010).

Berdasarkan hasil diatas diperoleh nilai Kontainer Indeks (CI) sebesar 6\%. Menurut WHO Nilai kontainer indeks $>5 \%$ merupakan nilai yang tinggi yang dapat digunakan sebagai indikator kecenderungan terjadinya penularan penyakit karena tingginya tempat-tempat perindukan. Tetapi bila dimasukkan kedalam skala tabel Density figure nilai tersebut masih digolongkan dan kedalam status sedang.

Kepadatan Larva nyamuk Aedes aegypti dengan nilai House indeks sebesar 15\%. House Index merupakan salah satu indikator yang digunakan untuk menghitung resiko penyebaran penyakit. Indeks ini memberikan petunjuk tentang persentase rumah yang positif untuk perkembangbiakan hal ini dapat digunakan untuk menunjukkan populasi manusia yang beresiko terkena DBD. Kontainer indeks memberikan gambaran presentae kontainer yang positif jentik Aedes. Dimana pada penelitian ini ditemukan nilai Kontainer indeks (CI) sebesar 6\% dan Breteau Indeks (BI) sebesar 32\%. Dengan nilai skala Density figure pada skala $2-4$ yang mengindikasikan resiko penularan sedang. Dengan nilai ini meskipun wilayah kelurahan Mamunyu masih merupakan wilayah non endemis tetapi berdasarkan hasil penelitian ini dapat menjadi wilayah berindikasi untuk terjadi penularan karena banyaknya ditemukan kontainer-kontainer yang potensial sebagai tempat perindukan larva nyamuk.

\section{KESIMPULAN}

Kesimpulan dari penelitian ini adalah Nilai House Indeks diwilayah endemis yaitu 35\%, Kontainer indeks 5\% dan Breteaue Indeks $105 \%$ dengan resiko penularan tinggi sedangkan nilai House Indeks diwilayah endemis yaitu $15 \%$, Kontainer indeks $6 \%$ dan 
Breteaue Indeks $32 \%$ dengan resiko penularan sedang.

\section{DAFTAR PUSTAKA}

Departemen Kesehatan RI. (2015, Maret 5). Buletin Jendela Epidemiologi Demam Berdarah Dengue 2010. Retrieved from Departemen Kesehatan RI: www.depkes. go.id

Dinas Kesehatan Kabupaten Mamuju. (2016). Profil Dinas Kesehatan Kabupaten Mamuju Provinsi Sulawesi Barat 2015. Mamuju: Dinas Kesehatan Kabupaten Mamuju.

Hendri, R. (2010). Tempat Perkembangan Nyamuk Aedes spp di Pasar Wisata Pangandaran. Jurnal Equator Vol. 2 No. 1, 23-31.

Kementerian Kesehatan RI. (2011). Profil Kesehatan Indonesia 2010. Jakarta: Kementerian Kesehatan RI.
Penturi, W. (2011). Analisa Kepadatan Larva Nyamuk Culicude dan Anophelidae pada Tempat Perindukan di Negeri Kamarian Kecamatan Kairatu Kabupaten Seram Bagian Barat (SBB). Jurnal Molucca Medika vol 4 No. 1.

Ramadhani. (2013). Kepadatan dan Penyebaran Aedes aegypti Terhadap Infeksi Dengue Setelah Penyuluhan DBD di Kelurahan Paseban, Jakarta Pusat.

Soegijanto, S. (2006). Demam Berdarah Dengue. Surabaya: Airlangga University Press.

WHO. (2004). Panduan Lengkap Pencegahan dan Pengendalian Dengue dan Demam Berdarah Dengue. Jakarta: EGC. 